\title{
PENGARUH PENGGUNAAN BAHAN AJAR BERBASIS ANDROID DAN TIPE KEPRIBADIAN TERHADAP KEMAMPUAN KOMUNIKASI MATEMATIS CALON GURU
}

\author{
Alberta Parinters Makur ${ }^{1}$, Yohanes Kurniawan ${ }^{2}$, Bedilius Gunur ${ }^{3}$ \\ ${ }^{1,2,3}$ STKIP Santu Paulus Jl.A. Yani no 10, Ruteng, NTT, Indonesia
}

\begin{abstract}
This research aims to determine the effect of use an android application compared to conventional teaching materials on Trigonometry courses on the mathematical communication skills of student candidates regarding personality type. The research method was use quasi-experiment with the population of first grade at Department of Mathematics Education of STKIP Santu Paulus Ruteng and the sample was taken from 2 classes. Data were through by questionnaires and mathematical communication test which were then analyzed by two-way ANOVA test. Data analysis and interpretation showed that: (1) students who were taught using the help of Android-based teaching materials had better mathematical communication skills than students taught conventionally; (2) there was an interaction between learning media and personality type on mathematical communication skills. The findings point to recommendations that the use of appropriate instructional media could be used to improve students' mathematical communication skills and would facilitate the learning process of mathematics.
\end{abstract}

Keywords: android teaching materials; mathematical communication skills; personality type

\section{PENDAHULUAN}

Kurikulum Program Studi Pendidikan Matematika Sekolah Tinggi Keguruan dan Ilmu Pendidikan (STKIP) Santu Paulus memasukkan Mata Kuliah Trigonometri sebagai salah satu mata kuliah wajib bagi mahasiswa. Namun, hasil UN SMA tahun ajaran 2016/2017, persentase penguasaan materi pada indikator-indikator soal trigonometri di tingkat nasional masih tergolong rendah, yaitu dibawah 51\% (Puji, 2017). Hal tersebut menunjukkan bahwa penguasaan materi trigonometri lulusan SMA yang melanjutkan ke perguruan tinggi pun masih rendah. Termasuk yang melanjutkan studinya ke STKIP Santu Paulus.

Daya serap materi trigonometri yang tergolong rendah memberi ruang untuk mengembangkan hal baru guna memaksimalkan potensi lulusan SMA ini. Sebagai Lembaga Pendidik calon guru, STKIP Santu Paulus khususnya Prodi Pendidikan Matematika mempunyai komitmen agar masalah ini dapat diselesaikan. Cara yang dapat dilakukan adalah mengajarkan kepada calon guru matematika secara maksimal materi 
trigonometri. Misalkan dengan menyediakan sumber belajar yang memudahkan pembelajaran trigonometri.

Penggunaan bahan ajar berbasis aplikasi android merupakan alternatif untuk mengatasi kesulitan tersebut. Smartphone android lebih mudah dibawa, mudah dipakai, dan dapat dipakai secara terus-menerus. Bahan ajar yang dapat diakses atau digunakan menggunakan perangkat smartphone menjadi salah satu pertimbangan dalam pengembangan bahan ajar. Menurut survey yang dilakukan oleh Cambridge Internasional, menunjukkan bahwa sekitar dua pertiga (67\%) pelajar di Indonesia menggunakan smartphone di dalam pelajaran kelas, dan sekitar $81 \%$ untuk mengerjakan pekerjaan rumah (Harususilo, 2018). Oleh karena itu, dapat belajar menggunakan media tersebut kapan saja dan dimana saja (mobile learning).

Penggunaan smartphone android dalam pembelajaran sudah banyak diteliti dan banyak juga yang sudah menerapkannya. Penggunaan sarana pembelajaran yang paling efektif zaman ini adalah m-learning (mobile learning) yakni penggunaan perangkat smarphone untuk pembelajaran (Toktarova, Blagova, Filatova, \& Kuzmin, 2015; Martono \& Nurhayati, 2014; Joshi, Shete, \& Somani, 2015; Woodcock, Middleton, \& Nortcliffe, 2012). Martono \& Nurhayati (2014) mengungkapkan bahwa tren baru penggunaan e-learning adalah menggunakan mobile learning atau m-learning yakni menggunakan smartphone berbasis android, IOS atau windows phone. Joshi, et al (2015) menyatakan bahwa mobile learning adalah "next generation" e-learning yang dapat digunakan dalam proses pembelajaran.

Meskipun begitu peserta didik dan pendidik lebih tertarik dengan fitur-fitur yang lebih familiar bagi mereka misalnya: facebook, twitter, instagram (Woodcock, et al, 2012). Walaupun demikian, belum banyak pembelajaran yang dikembangkan atau dilaksanakan di sekolah dengan menggunakan media smartphone. Jadi, dapat disimpulkan bahwa meskipun Indonesia merupakan salah satu pengguna terbesar smartphone android di dunia, namun penggunaan android sebagai salah satu sarana atau bahan ajar jarang dilakukan.

Berdasarkan permasalahan di atas, maka akan dikembangkan suatu bahan ajar lengkap dengan materi trigonometri berbasis aplikasi android. Pengembangan bahan ajar tersebut, disamping untuk meningkatkan penguasaan materi trigonometri juga dapat meningkatkan kemampuan berpikir tingkat tinggi mahasiswa calon guru. Hal ini 
didorong pernyataan Mcgraw \& Rubinstein-ávila (2009) yang menekankan untuk menjadi sukses di abad ke-21, seseorang harus menjadi pemikir kritis, pemecah masalah, kolaborator, melek informasi dan teknologi, fleksibel dan mudah beradaptasi, inovatif dan kreatif, komunikator yang efektif, dan inisiator. Proses pembelajaran yang mendukung pengembangan kemampuan berpikir tingkat tinggi sangat diperlukan dalam pendidikan untuk memaksimalkan potensi yang dimiliki seseorang (Makur, Prahmana, \& Gunur, 2018; Nendi, Mandur, \& Makur, 2017).

Penggunaan aplikasi pembelajaran berupa aplikasi android lebih dimaksudkan membantu mahasiswa untuk dapat mempelajari materi pembelajaran secara individual. Oleh karena sifatnya yang individual, maka akan dilihat efeknya terhadap kemampuan komunikasi matematis. Setiap orang diharapkan memiliki kemampuan komunikasi matematis yang baik. Proses perkuliahan matematika menuntut mahasiswa calon guru mampu mengkomunikasikan pemahaman matematikanya agar pemahaman tersebut bisa dimengerti oleh orang lain. Dengan mengkomunikasikan ide-ide matematisnya kepada orang lain, seorang mahasiswa calon guru bisa meningkatkan pemahaman matematisnya. Komunikasi mempunyai hubungan yang sangat kuat dengan proses matematis yang lain dimana komunikasi diperlukan untuk melengkapi setiap proses matematis yang lain (Fisher, 2006; Kaye, Yeager, \& Reed, 2008; Kosko \& Wilkins, 2006; Lagur, Makur, \& Ramda, 2018; Lim \& Chew, 2007; Wichelt, 2009)

Efek penggunaan aplikasi pembelajaran berbasis android terhadap kemampuan komunikasi matematis perlu ditinjau dari tipe kepribadian mahasiswa calon guru. Dengan tetap memperhatikan pentingnya peran media dalam menyampaikan pembelajaran matematika, faktor individual mahasiswa merupakan faktor internal yang juga berpengaruh dalam proses belajar. Salah satu faktor individual yang perlu diperhatikan adalah karakteristik seseorang, termasuk tipe kepribadian mahasiswa yaitu introvert dan ekstrovert. Karakteristik yang dominan pada tipe introvert adalah pendiam, teliti, hati-hati dalam mengambil keputusan, dan kurang berani dalam mengambil keputusan, sedangkan pada tipe ekstrovert adalah sosialisasi yang tinggi untuk berinteraksi, aktif, berani mengambil resiko (Sujanto, Lubis, \& Hadi, 2004)

Berdasarkan uraian di atas, maka artikel ini memaparkan pengaruh penggunaan bahan ajar berbasis android dan tipe kepribadian terhadap kemampuan komunikasi matematis mahasiswa calon guru STKIP Santu Paulus Ruteng. 


\section{METODE PENELITIAN}

Penelitian ini dilakukan dengan menggunakan pendekatan penelitian kuantitatif. Metode penelitian yang digunakan adalah kuasi-eksperimen dengan populasi mahasiswa tingkat 1 Program Studi Pendidikan Matematika STKIP Santu Paulus dan sampel diambil dari 2 kelas pada mata kuliah Trigonometri. Desain penelitian yang digunakan dalam penelitian ini adalah design treatment by level dengan tingkat $(2 \times 2)$. Variabel bebas adalah bahan ajar dan tipe kepribadian mahasiswa calon guru (variabel moderator), sedangkan variabel terikatnya adalah kemampuan komunikasi matematis mahasiswa calon guru. Dengan desain ini akan terlihat pengaruh perlakuan (bahan ajar statistika elementer) terhadap kemampuan komunikasi matematis mahasiswa calon guru ketika dilihat dari tipe kepribadian mahasiswa calon guru. Desain matriks dapat dilihat pada Tabel 1.

Tabel 1. Desain Penelitian

\begin{tabular}{ccc}
\hline Tipe Kepribadian & \multicolumn{2}{c}{ Bahan Ajar } \\
\cline { 2 - 3 } & Android $\left(A_{1}\right)$ & Konvensional $\left(A_{2}\right)$ \\
\hline Introvert $\left(B_{1}\right)$ & $A_{1} B_{1}$ & $A_{2} B_{1}$ \\
Ekstrovert $\left(B_{2)}\right.$ & $A_{1} B_{2}$ & $A_{2} B_{2}$ \\
\hline
\end{tabular}

Desain ini digunakan untuk melihat pengaruh penggunaan bahan ajar berbasis android dengan bahan ajar konvensional terhadap kemampuan komunikasi matematis mahasiswa calon guru. Pengaruh yang ingin dilihat adalah: (1) Efek utama $\left(A_{1} \operatorname{dan} A_{2}\right)$ : Perbedaan kemampuan komunikasi matematis mahasiswa bahan ajar berbasis android dengan bahan ajar konvensional terhadap kemampuan komunikasi matematis mahasiswa calon guru, dan (2) Efek interaksi $\left(A_{i} \times B\right.$ and $\left.Y\right)$ : Interkasi antara bahan ajar dan tipe kepribadian terhadap kemampuan komunikasi matematis

Perlakuan (treatment) yang diberikan dalam penelitian ini adalah penerapan bahan ajar berbasis android dalam proses pembelajaran untuk meningkatkan kemampuan komunikasi matematis mahasiswa calon guru. Berdasarkan perlakuan di atas, kelompok subjek penelitian dibedakan menjadi dua kelompok, yaitu kelompok dengan perlakuan menggunakan bahan ajar berbasis android ( 1 kelas eksperimen) dan kelompok dengan bahan ajar konvensional (1 kelas kontrol). Setelah mahasiswa calon guru diberikan pembelajaran dengan bahan ajar masing-masing, mahasiswa calon guru diberikan posttest untuk mengukur kemampuan komunikasi matematis.

Perlakuan yang dilakukan pada setiap kelas dalam penelitian terbatas pada 
beberapa hal berikut:

1) Materi pembelajaran

Materi pembelajaran yang digunakan dalam penelitian ini adalah sudut, hubungan perbandingan sisi-sisi yang bersesuaian dalam beberapa segitiga siku-siku sebangun, membedakan sudut positif dan sudut negatif dan dapat mengubah ukuran sudut dari radian ke derajat, serta sebaliknya, mengidentifikasi segitiga siku-siku, mendefinisikan enam fungsi trigonometri dengan menggunakan perbandingan sudut-sudut pada segitiga siku-siku, menentukan nilai fungsi trigonometri dari sudut $30^{\circ}, 45^{\circ}$, dan $90^{\circ}$, dan menentukan nilai fungsi trigonometri dari quadrantal angles.

2) Pelaksanaan perlakuan

Pelaksanaan perlakuan yang diberikan kepada mahasiswa calon guru berbeda dimana mahasiswa calon guru dalam kelompok eksperimen diberi pembelajaran menggunakan bahan ajar berbasis android dan kelompok kontrol diberi pembelajaran menggunakan bahan ajar konvensional. Pelaksanaan perlakuan dengan menggunakan dua bahan ajar pembelajaran tersebut dibagi menjadi tiga yaitu 1 pertemuan untuk pemberian instrumen tipe kepribadian pada kelas eksperimen dan kelas kontol untuk mengkategorikan mahasiswa calon guru ke dalam tipe ektrovert dan introvert, 6 pertemuan digunakan untuk perlakuan, yaitu bahan ajar berbasis android pada kelas eksperimen dan bahan ajar konvensional pada kelas kontrol, dan 1 pertemuan untuk pelaksanaan tes akhir yang mengukur kemampuan komunikasi matematis mahasiswa calon guru pada kelas eksperimen dan kelas kontol.

3) Soal-soal latihan

Setiap mahasiswa (kelas kontrol maupun kelas eksperimen) diberikan latihan soal yang memenuhi indikator kemampuan komunikasi matematis; (a) dosen memberikan materi pembelajaran trigonometri, contoh soal, dan latihan soal yang membutuhkan kemampuan komunikasi matematis dalam penyelesaiannya, (b) mengadakan tes kemampuan komunikasi matematis, setelah beberapa kali melakukan proses pembelajaran.

Hipotesis statistik penelitian ini diuji dengan menggunakan Analisis Varians (ANAVA) dua jalur dengan tujuan untuk menguji main effect dan interaction effect (efek utama berdasarkan bahan ajar dan pengaruh interaksi antar bahan ajar (A) dan tipe kepribadian (B). Main effect bertujuan untuk melihat perbedaan rata-rata kemampuan 
komunikasi matematis mahasiswa ditinjau dari bahan ajar yang digunakan dalam proses pembelajaran matematika. Apabila terdapat perbedaan, berdasarkan nilai rata-rata maka ditentukan strategi mana yang lebih baik dalam meningkatkan kemampuan komunikasi matematis mahasiswa selama proses pembelajaran.

Uji selanjutnya adalah uji interaksi untuk melihat ada tidaknya interaksi antara bahan ajar dan tipe kepribadian terhadap kemampuan komunikasi matematis. Apabila terdapat pengaruh interaksi antara $\mathrm{A}$ dan $\mathrm{B}$, pengujian selanjutnya dilakukan dengan menggunakan uji Tuckey (digunakan karena banyaknya sampel setiap kelas berbeda) yaitu menguji efek sederhana (simple effect), yang dimaksudkan untuk menguji perbedaan kemampuan komunikasi matematis kelompok mahasiswa dengan tipe kepribadian introvert. Selain itu, diuji perbedaan kemampuan komunikasi matematis kelompok tipe kepribadian ekstrovert setelah keduanya diberikan perlakuan berbeda.

\section{HASIL DAN PEMBAHASAN}

Dari hasil pengambilan sampel, mahasiswa dikelompokkan menjadi 2 kelompok, yakni mahasiswa yang memiliki tipe kepribadian introvert dan tipe kepribadian ekstrovert baik pada kelompok kontrol maupun kelompok eksperimen. Kemudian dari masing-masing kelompok tersebut diberikan perlakuan dan posttest, diperoleh hasil dalam 4 kelompok yang dilihat kemampuan komunikasi matematisnya yaitu: kelompok $A_{1} B_{1}$, kelompok $A_{2} B_{1}$, kelompok $A_{1} B_{2}$, dan kelompok $A_{2} B_{2}$. Adapun komposisi sampel terlihat pada Tabel 2 berikut ini.

Tabel 2. Kategori Mahasiswa

\begin{tabular}{lcc}
\hline Tipe Kepribadian & \multicolumn{2}{c}{ Bahan Ajar } \\
\cline { 2 - 3 } & Android $\left(A_{1}\right)$ & Konvensional $\left(A_{2}\right)$ \\
\hline Ekstovert $\left(B_{1}\right)$ & 17 & 20 \\
Introvert $\left(B_{2}\right)$ & 17 & 21 \\
\hline
\end{tabular}

Pengujian hipotesis nol menguji ada tidaknya interaksi antara bahan ajar dan tipe kepribadian terhadap kemampuan komunikasi matematis. Uji hipotesis ini dilakukan dengan menggunakan bantuan SPSS Statistics 17.0 yakni dengan General Linear Model Univariate.

Sebelum dilakukan uji dengan menggunakan ANAVA terlebih dahulu peneliti memastikan bahwa data sudah memenuhi asumsi berikut: (1) variabel dependen yaitu kemampuan komunikasi matematis diukur pada level kontinu, yaitu variabel interval; 
(2) dua variabel independen yaitu tipe kepribadian dan jenis bahan ajar yang digunakan masing-masing terdiri dari dua atau lebih kategori, kelompok independen. Tipe kepribadian terbagi menjadi introvert dan ekstovert lalu jenis bahan ajar yang digunakan terbagi menjadi bahan ajar berbasis android dan bahan ajar konvensional; (3) terdapat independensi pengamatan, yang berarti bahwa tidak ada hubungan antara pengamatan dalam setiap kelompok atau antara kelompok itu sendiri. Setiap peserta menjadi anggota di setiap grup dan tidak ada peserta berada di lebih dari satu grup; (4) tidak terdapat pencilan yang signifikan. Data kemampuan komunikasi matematis mahasiswa calon guru tidak memiliki pencilan (outlier); (5) variabel dependen terdistribusi secara normal untuk setiap kombinasi dari kedua variabel independen. Berdasarkan Tabel 3 pada kolom Shapiro-Wilk (dipilih karena banyaknya data kurang dari 2000) diperoleh semua nilai signifikansi (Sig.) lebih besar dari taraf signifikansi yang digunakan dalam penelitian ini yaitu $\alpha=0.05$. Karena nilai $\mathrm{p}>\alpha$ maka sampel berasal dari populasi yang berdistribusi normal; dan (6) setiap kelompok memiliki homogenitas varians untuk setiap kombinasi kelompok dari dua variabel independen.

Tabel 3. Rangkuman Hasil Perhitungan Uji Normalitas

\begin{tabular}{rcccccc}
\hline & \multicolumn{3}{c}{ Kolmogorov-Smirnov $^{\mathrm{a}}$} & \multicolumn{3}{c}{ Shapiro-Wilk } \\
\cline { 2 - 7 } & Statistic & $\mathrm{df}$ & Sig. & Statistic & $\mathrm{df}$ & Sig. \\
A1 & .082 & 34 & $.200^{*}$ & .980 & 34 & .768 \\
A2 & .127 & 41 & .094 & .953 & 41 & .089 \\
A1B1 & .112 & 17 & $.200^{*}$ & .935 & 17 & .268 \\
A1B2 & .172 & 17 & .191 & .916 & 17 & .128 \\
A2B1 & .107 & 20 & $.200^{*}$ & .978 & 20 & .912 \\
A2B2 & .180 & 21 & .074 & .912 & 21 & .061 \\
\hline
\end{tabular}

Uji homogenitas varians kelompok siswa yang menggunakan bahan ajar berbasis android $\left(\mathrm{A}_{1}\right)$ dan kelompok siswa yang menggunakan bahan ajar konvensional $\left(\mathrm{A}_{2}\right)$ dapat dilihat pada Tabel 4.

Tabel 4. Hasil Uji Homogenitas berdasarkan Bahan Ajar

\begin{tabular}{|c|c|c|c|}
\hline Levene Statistic & df1 & df2 & Sig. \\
\hline 0.407 & 1 & 73 & .524 \\
\hline
\end{tabular}

Uji homogenitas varians kelompok siswa yang menggunakan bahan ajar berbasis android $\left(\mathrm{A}_{1}\right)$ dan kelompok siswa yang menggunakan bahan ajar konvensional $\left(\mathrm{A}_{2}\right)$ dapat dilihat pada ditinjau dari tipe kepribadian terhadap kemampuan komunikasi 
matematis dapat dilihat pada Tabel 5.

Tabel 5. Hasil Uji Homogenitas berdasarkan Bahan Ajar dan Tipe Kepribadian

\begin{tabular}{|c|c|c|c|}
\hline Levene Statistic & df1 & df 2 & Sig. \\
\hline 0.534 & 3 & 71 & .659 \\
\hline
\end{tabular}

Hasil analisis dapat dilihat pada Tabel 6 baris Bahan Ajar * Tipe Kepribadian. Hasil analisis menunjukkan adanya interaksi antara bahan ajar dan tipe kepribadian ( $\mathrm{p}=$ 0,053 yang mengakibatkan ditolaknya $\mathrm{H}_{0}$ yang menyatakan tidak adanya interaksi antara strategi dan penalaran). Artinya, terdapat interaksi antara jenis bahan ajar yang digunakan dengan tipe kepribadian terhadap kemampuan komunikasi matematis mahasiswa calon guru. Sedangkan, bentuk interaksi antara bahan ajar dan tipe kepribadian terlihat dalam Gambar 1.

Tabel 6. Hasil Uji

\begin{tabular}{lrrrrl}
\hline Source & Type III Sum of Squares & df & Mean Square & F & Sig \\
\hline Corrected Model & $4796.430 \mathrm{a}$ & 3 & 1598.810 & 3.818 & .014 \\
Intercept & 183266.067 & 1 & 183266.067 & 437.665 & .000 \\
Strategi & 2241.343 & 1 & 2241.343 & 5.353 & .024 \\
TipeKepribadian & 1154.383 & 1 & 1154.383 & 2.757 & .101 \\
BahanAjar * TipeKepribadian & 1625.623 & 1 & 1625.623 & 3.882 & .053 \\
Error & 29730.237 & 71 & 418.736 & & \\
Total & 215583.000 & 75 & & & \\
Corrected Total & 34526.667 & 74 & & & \\
\hline
\end{tabular}

Estimated Marginal Means of Komunikasi

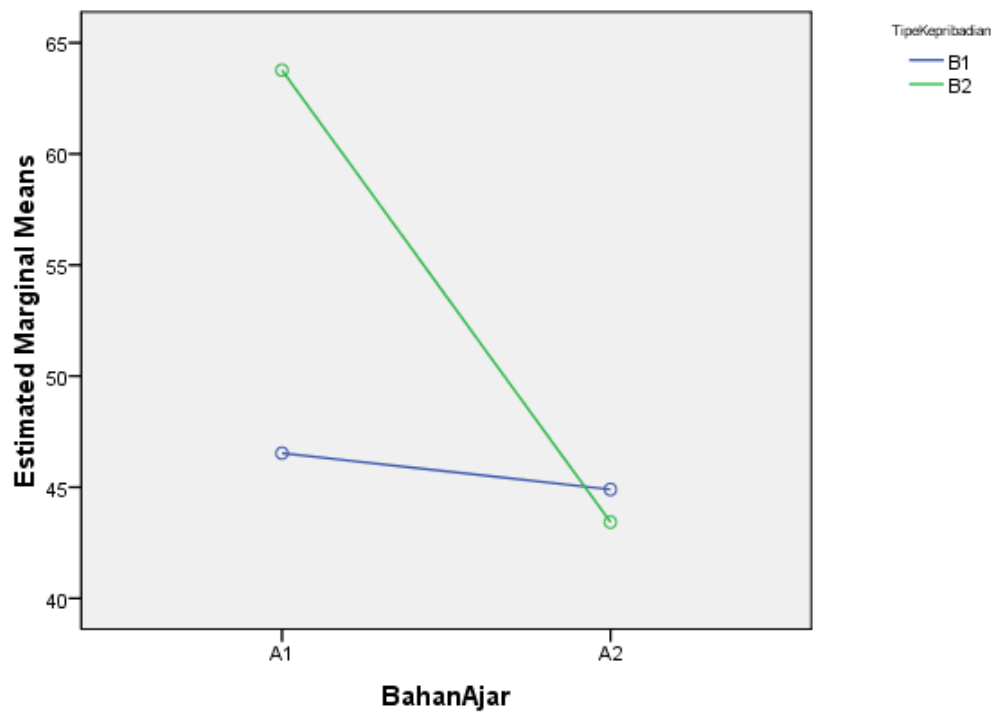

Gambar 1. Interaksi antara Bahan Ajar dan Tipe Kepribadian

Berdasarkan Gambar 1 di atas, garis B1 memperlihatkan rata-rata kemampuan komunikasi matematis kelompok mahasiswa tipe kepribadian ekstrovert yang 
menggunakan bahan ajar berbasis android lebih tinggi daripada rata-rata hasil belajar matematika kelompok mahasiswa tipe kepribadian ekstrovert yang menggunakan bahan ajar konvensional. Sedangkan, garis B2 adalah rata-rata hasil belajar matematika kelompok mahasiswa tipe kepribadian introvert yang menggunakan bahan ajar berbasis android lebih tinggi daripada rata-rata hasil belajar matematika kelompok mahasiswa tipe kepribadian introvert yang menggunakan bahan ajar konvensional.

Kemiringan dua buah garis pada Gambar 1 di atas menunjukkan bahwa terdapat interaksi di antara dua variabel bebas terhadap variabel terikat. Dengan kata lain, interaksi dapat diartikan bahwa pengaruh bahan ajar terhadap kemampuan komunikasi matematis tergantung dari tipe kepribadian mahasiswa. Karena terjadi interaksi, efek perlakuan tidak dapat terbaca secara langsung. Perlu dilakukan uji lanjutan atau post hoc (dengan menggunakan uji Tuckey) untuk melihat efek perlakuan. Output SPSS untuk hasil uji ini terlihat pada Tabel 7 berikut.

Tabel 7. Uji Berdasarkan Kategori

\begin{tabular}{llllll}
\hline \multicolumn{1}{c}{ Source } & Type III Sum of Squares & df & Mean Square & F & Sig \\
\hline Corrected Model & $4796.430 \mathrm{a}$ & 3 & 1598.810 & 3.818 & .014 \\
Intercept & 183266.067 & 1 & 183266.067 & 437.665 & .000 \\
Category & 4796.430 & 3 & 1598.810 & 3.818 & .014 \\
Error & 29730.237 & 71 & 418.736 & & \\
Total & 215583.000 & 75 & & & \\
Corrected Total & 34526.667 & 74 & & & \\
\hline
\end{tabular}

Tabel 7 menunjukkan bahwa keempat kombinasi $\left(A_{1} B_{1}, A_{1} B_{2}, A_{2} B_{1}\right.$, dan $\left.A_{2} B_{2}\right)$ dalam variabel kategori menunjukkan nilai yang signifikan $(\mathrm{p}=0.014)$. Karena signifikan maka dapat dilanjutkan dengan melihat ke bagian multiple comparisons atau post hoc.

Jika pada analisis varians di atas hanya diketahui ada perbedaan kemampuan komunikasi matematis ditinjau dari kombinasi bahan ajar dan tipe kepribadian saja, maka pada post hoc dapat dilihat secara mendetail pada Tabel 8. 
Tabel 8. Uji Post Hoc

\begin{tabular}{lllllll}
\hline \multirow{2}{*}{ (I) Category } & \multirow{2}{*}{ (I) Category } & \multirow{2}{*}{ Mean Difference (I-J) } & \multirow{2}{*}{ Std. Error } & \multirow{2}{*}{ Sig. } & \multicolumn{2}{c}{ 95\% Confidence Interval } \\
\hline A1B1 & A1B2 & -17.24 & 7.019 & .076 & -35.70 & 1.23 \\
& A2B1 & 1.63 & 6.750 & .995 & -16.13 & 19.39 \\
& A2B2 & 3.10 & 6.676 & .967 & -14.46 & 20.67 \\
A1B2 & A1B1 & 17.24 & 7.019 & .076 & -1.23 & 35.70 \\
& A2B1 & $18.86^{*}$ & 6.750 & .033 & 1.10 & 36.62 \\
& A2B2 & $20.34^{*}$ & 6.676 & .017 & 2.77 & 37.90 \\
\hline
\end{tabular}

Berdasarkan Tabel 8, dapat disimpulkan: (1) karena nilai Sig. $=0.076$ berarti tidak ada perbedaan kemampuan komunikasi matematis yang signifikan antara penggunaan bahan ajar berbasis android pada mahasiswa dengan tipe kepribadian ekstrovert, dan (2) Karena nilai Sig. $=0.017$ berarti ada perbedaan kemampuan komunikasi matematis yang signifikan antara penggunaan bahan ajar berbasis pada mahasiswa dengan tipe kepribadian introvert.

Hasil pengujian hipotesis berdasarkan analisis varian (ANAVA) dua jalan ditemukan bahwa terdapat perbedaan kemampuan komunikasi matematis kelompok mahasiswa yang menggunakan bahan ajar berbasis android dengan kemampuan komunikasi matematis kelompok mahasiswa yang menggunakan bahan ajar konvensional. Pengujian dilanjutkan dengan uji Tuckey maka kemampuan komunikasi matematis kelompok mahasiswa yang menggunakan bahan ajar berbasis android lebih tinggi dari kemampuan komunikasi matematis kelompok mahasiswa yang menggunakan bahan ajar konvensional.

Kenyataan ini dapat dijelaskan melalui beberapa alasan. Kemampuan komunikasi dapat ditingkatkan dengan mengoptimalkan keterlibatan pembelajar pada proses belajar (Lagur et al., 2018). Selain itu, penggunaan sarana pembelajaran yang paling efektif zaman ini adalah m-learning (mobile learning) yakni penggunaan perangkat smarphone untuk pembelajaran (Toktarova, Blagova, Filatova, \& Kuzmin, 2015; Martono \& Nurhayati, 2014; Joshi, Shete, \& Somani, 2015; Woodcock, Middleton, \& Nortcliffe, 2012). Bahan ajar berbasis android sedapat mungkin dianalogikan dengan kegiatan yang melibatkan mahasiswa dalam memahami konsep matematika lewat bantuan komputer sehingga kemampuan matematika mahasiswa dapat diasah secara maksimal karena mahasiswa mengerjakan suatu persoalan dalam bentuk permainan dengan kemampuan sendiri melalui trial and error dan mempermudah dosen dalam menilai kemampuan mahasiswa secara individu sehingga penanganan bagi mahasiswa yang mempunyai 
kemampuan kurang atau lebih dalam pemahaman matematika dapat segera mendapatkan stimulasi tambahan.

Pada penelitian bahan ajar berbasis android terlihat bahwa jika menggunakan media ini mahasiswa akan dapat bekerja sampai pada level tertinggi untuk tugas-tugas kognitif. Mereka mampu memanipulasi dalam menggunakan telepon genggam secara fisik, mereka dapat memberikan kemudahan bagi anak, mengembangkan koordinasi mata, meningkatkan motivasi dalam belajar, pembelajarannya berbentuk gabungan dari berbagai media seperti teks, suara, gambar, numerik, animasi dan video dalam satu software digital dengan bantuan komputer yang menghasilkan kualitas gambar 3D. Dengan demikian, gambar yang disajikan dalam ilustrasi lebih menarik dan hidup, sehingga mahasiswa lebih tertarik dan senang dalam belajar. Pembelajarannya lebih kepada praktek trial and error, sehingga mahasiswa dapat belajar dari sesuatu yang salah dan pendekatannya secara positif. Jika mahasiswa memberikan jawaban yang salah mahasiswa tidak pernah dimarahi dan mendapat sanksi negatif dan bersifat individual sehingga dapat menyesuaikan terhadap kemampuannya sendiri dan memudahkan dosen untuk menilai mahasiswa. Tetapi dalam pembelajaran komputer, guru harus banyak mengerti penggunaan komputer untuk mahasiswa didiknya karena mereka harus membimbing dan mengatasi bila mahasiswa mengalami kesalahan dalam penggunaan komputer. Hal inilah yang mengakibatkan rata-rata kemampuan komunikasi matematis kelompok mahasiswa yang menggunakan bahan ajar berbasis android lebih tinggi dari bahan ajar konvensional.

Sedangkan bahan ajar konvensional penyajian materinya bersifat dua dimensi menjadi lebih monoton sehingga mahasiswa kurang tertarik untuk mempelajarinya. Hal inilah yang mengakibatkan rata-rata kemampuan komunikasi matematis kelompok mahasiswa yang menggunakan bahan ajar konvensional lebih rendah dari bahan ajar berbasis android.

Hasil pengujian hipotesis berdasarkan analisis varian (ANAVA) dua jalan ditemukan terdapat interaksi antara bahan ajar dan tipe kepribadian terhadap kemampuan komunikasi matematis. Kelompok mahasiswa yang memiliki tipe kepribadian introvert dan menggunakan bahan ajar berbasis android memperoleh kemampuan komunikasi matematis yang lebih tinggi dari mahasiswa yang menggunakan bahan ajar konvensional. Pada kelompok mahasiswa yang memiliki tipe 
kepribadian ekstrovert dan menggunakan bahan ajar berbasis android memperoleh kemampuan komunikasi matematis yang lebih rendah dari mahasiswa yang menggunakan bahan ajar konvensional. Dengan demikian dapat diketahui bahwa terdapat pengaruh dari masing-masing bahan ajar yang diberikan baik itu bahan ajar berbasis android maupun bahan ajar konvensional yang berkaitan dengan tipe kepribadian mahasiswa dan memberikan pengaruh yang berbeda terhadap hasil belajar anak.

Ketepatan penggunaan bahan ajar yang sesuai dengan karakteristik mahasiswa serta kemampuan mahasiswa dalam mengembangkan pemahaman konsep matematika sangat dibutuhkan. Hal ini tentunya harus didukung oleh peran penting dari dosen, dimana tingkat kreativitas dosen dalam mengembangkan bahan ajar dengan memperhatikan karakteristik individu mahasiswa dapat mempengaruhi pemahaman mahasiswa dalam pembelajaran matematika. Pemilihan bahan ajar yang tepat dan potensi yang dimiliki mahasiswa dalam hal ini adalah tipe kepribadian berhubungan dengan kemampuan memecahkan masalah, akan memaksimalkan proses kegiatan belajar mengajar di kelas dalam rangka meningkatkan kemampuan komunikasi matematis.

Untuk kelompok mahasiswa mempunyai tipe kepribadian introvert, ditemukan bahwa terdapat perbedaan yang signifikan antara kemampuan komunikasi matematis kelompok mahasiswa yang menggunakan bahan ajar berbasis android dengan kemampuan komunikasi matematis kelompok mahasiswa yang menggunakan papan magnetis. Hal ini ditunjukkan dengan pengujian menggunakan uji Tuckey yang mempunyai arti bahwa khusus kelompok mahasiswa yang mempunyai tipe kepribadian introvert, rata-rata kemampuan komunikasi matematis kelompok mahasiswa yang menggunakan bahan ajar berbasis android lebih tinggi dari rata-rata kemampuan komunikasi matematis kelompok mahasiswa yang menggunakan bahan ajar papan magnetis.

Kenyataan tersebut dapat dijelaskan bahwa mahasiswa dengan tipe kepribadian introvert, biasanya pendiam, pemalu, introspektif, suka menyendiri, takut mengambil risiko, pesimis, menyukai hal-hal yang dirasa aman, tidak buru-buru, teliti, suka berpikir sebelum bertindak, lebih cenderung tertutup, kurang suka bertanya dan berdebat, kurang bergaul dan berteman, kurang suka bekerja berkelompok. Namun mereka cenderung 
pemikir, teliti, mandiri, disiplin, teratur dan konsisten serta percaya pada kemampuan diri sendiri, sangat memungkinkan bagi mahasiswa yang berkepribadian introvert menggunakan bahan ajar berbasis android. Dengan cara ini mereka lebih hati-hati, lebih kontrol dalam menyelesaikan permasalahan. Sehingga pada akhirnya akan berdampak positif terhadap hasil belajarnya. Karena itu, bahan ajar berbasis android sesuai dengan mahasiswa yang memiliki tipe kepribadian introvert.

Sebaliknya dengan bahan ajar konvensional, kelompok mahasiswa yang memiliki tipe kepribadian introvert kurang mendapat kesempatan untuk mengembangkan kemampuan matematika dengan baik. Mahasiswa dituntut untuk belajar dalam kelompok sehingga mahasiswa dengan tipe kepribadian introvert kurang termotivasi dalam mengoptimalkan kemampuannya. Oleh karena itu kelompok mahasiswa yang menggunakan bahan ajar konvensional dan memiliki tipe kepribadian introvert tidak dapat mencapai nilai yang optimal pada pelajaran matematika.

Untuk kelompok mahasiswa yang memiliki tipe kepribadian ekstrovert secara statistik menunjukkan bahwa terdapat perbedaan yang signifikan antara kemampuan komunikasi matematis kelompok mahasiswa yang menggunakan bahan ajar berbasis android dengan kemampuan komunikasi matematis kelompok mahasiswa yang menggunakan bahan ajar konvensional. Hal ini ditunjukkan dengan pengujian menggunakan uji Tuckey diperoleh bahwa khusus kelompok mahasiswa yang memilki tipe kepribadian ekstrovert, rata-rata kemampuan komunikasi matematis kelompok mahasiswa yang menggunakan bahan ajar konvensional lebih tinggi daripada rata-rata kemampuan komunikasi matematis kelompok mahasiswa yang menggunakan bahan ajar berbasis android.

Kenyataan tersebut di atas dapat dijelaskan bahwa mahasiswa dengan tipe kepribadian ekstrovert, biasanya suka tantangan, berani mengambil resiko, mudah menyesuaikan diri dengan lingkungan, memiliki rasa ingin mencoba sesuatu yang baru. Sehingga kurang efektif jika menggunakan bahan ajar berbasis android, karena dengan media tersebut kurang adanya interaksi dengan teman dan hanya terpacu pada layar telepon genggam sehingga mahasiswa dengan tipe kepribadian ekstrovert lebih cepat bosan dibandingkan menggunakan bahan ajar konvensional. Oleh karena itu, kelompok mahasiswa yang menggunakan bahan ajar berbasis android dan memiliki tipe kepribadian ekstrovert tidak dapat mencapai nilai yang optimal pada pelajaran 
matematika.

Bagi kelompok mahasiswa yang memiliki tipe kepribadian ekstrovert lebih cenderung suka menggunakan bahan ajar konvensional, sebab dalam kelompokkelompok kecil berpeluang besar bagi mahasiswa berinteraksi saling mengoreksi dan kerjasama dalam kelompok sehingga sangat memungkinkan bagi mahasiswa yang berkepribadian ekstrovert yang memiliki sifat terbuka, aktif, suka menerima informasi dan koreksi orang lain, suka bertanya dan menanggapi pembicaraan, suka bergaul dan berteman, dapat menerima dan menyesuaikan dalam kelompok dibandingkan menggunakan bahan ajar berbasis android yang mengerjakan permainan dengan individual. Oleh karena itu, bahan ajar konvensional sesuai dengan mahasiswa yang memiliki tipe kepribadian ekstrovert.

\section{SIMPULAN DAN SARAN}

Berdasarkan uraian sebelumnya yang telah dilakukan, dapat disimpulkan bahwa (1) kemampuan komunikasi matematis antara mahasiswa calon guru yang diberi bahan ajar berbasis android dalam pembelajaran matematika lebih tinggi daripada yang menggunakan bahan ajar konvensional dan (2) ada pengaruh interaksi antara bahan ajar dan tipe kepribadian terhadap kemampuan komunikasi matematis mahasiswa calon guru.

Pembelajaran dengan bahan ajar berbasis android harus berfungsi sebagai bahan ajar alternatif untuk diterapkan dalam pengembangan pembelajaran matematika di kelas, terutama untuk meningkatkan kemampuan komunikasi matematis. Selanjutnya, pembelajaran matematika dengan bahan ajar berbasis android harus dapat diterapkan dalam jangka waktu yang lebih lama, dengan tujuan menjadikan proses belajar lebih optimal. Selain itu, mahasiswa calon guru perlu terbiasa membaca berbagai sumber pembelajaran baik cetak maupun elektronik dan menulis kembali informasi yang diperoleh dalam bentuk catatan singkat.

\section{DAFTAR RUJUKAN}

Fisher, R. J. (2006). What is Action Research? An introduction to action research for community development . In Seminar on Human Resource Development through Agricultural Extensio (pp. 23-26). Tehran. Retrieved from https://cmsdata.iucn.org/downloads/what_is_action_research_apo_2004_.pdf 
Harususilo, Y. E. (2018, Desember 11). Wah, Siswa Indonesia Pemakai Teknologi Tertinggi Dunia! Ini 7 Faktanya. Retrieved from Kompas.com: https://edukasi.kompas.com/read/2018/12/11/08143651/wah-siswa-indonesiapemakai-teknologi-tertinggi-dunia-ini-7-faktanya

Joshi, R., Shete, V. V, \& Somani, S. B. (2015). Android Based Smart Learning and Attendance Management System, 4(6), 256-260. https://doi.org/10.17148/IJARCCE.2015.4655

Kaye, H. S., Yeager, P., \& Reed, M. (2008). Disparities in Usage of Assistive Technology Among People With Disabilities. Assistive Technology. https://doi.org/10.1080/10400435.2008.10131946

Kosko, K. W., \& Wilkins, J. L. M. (2006). Mathematical Communication and Its Relation to the Frequency of Manipulative Use Karl W. Kosko \& Jesse L. M. Wilkins Virginia Polytechnic Institute \& State University. International Electronic Journal of Mathematics Education, 5(2), 79-90.

Lagur, D. S., Makur, A. P., \& Ramda, A. H. (2018). Pengaruh Model Pembelajaran Kooperatif Tipe Numbered Head Together Terhadap Kemampuan Komunikasi Matematis. Mosharafa: Jurnal Pendidikan Matematika, 7(3), 357-368.

Lim, C. S., \& Chew, C. M. (2007). Mathematical Communication in Malaysian Bilingual Classrooms. In APEC-Tsukuba International Conference: Innovation of classroom teaching and learning through lesson study-focusing on mathematical communication (pp. 9-14). Tokyo.

Makur, A. P., Prahmana, R. C. I., \& Gunur, B. (2018). Kemampuan Berpikir Tingkat Tinggi, Peserta OSK Matematika Tingkat SD, dan Strategi Think, Talk, and Write. Jurnal Pendidikan Matematika, 12(2), 23-32. https://doi.org/https://doi.org/10.22342/jpm.12.2.5677.\%25p

Martono, K. T., \& Nurhayati, O. D. (2014). Implementation of Android Based Mobile Learning Application as A Flexible Learning, 11(3), 168-174.

Mcgraw, R., \& Rubinstein-ávila, E. (2009). Middle School Immigrant Students Developing Mathematical Reasoning in Spanish and English. Bilingual Research Journal. https://doi.org/10.1080/15235880802640656

Nendi, F., Mandur, K., \& Makur, A. P. (2017). Matematis Dalam Konsep-Konsep Matematika SMP. 166 Jurnal Pendidikan Dan Kebudayaan Missio, 9(2), 165173.

Puji, L. (2017). Kesalahan Siswa dalam Menyelesaikan Soal Trigonometri Kelas X SMA Negeri 1 Kartasura.

Sujanto, A., Lubis, H., \& Hadi, T. (2004). Psikologi Kepribadian. Jakarta: PT. Bumi Aksara. 
Toktarova, V. I., Blagova, A. D., Filatova, A. V., \& Kuzmin, N. V. (2015). Design and implementation of mobile learning tools and resources in the modern educational environment of university. Review of European Studies, 7(8), 318-324. https://doi.org/10.5539/res.v7n8p318

Wichelt, L. (2009). Communication: A Vital Skill of Mathematics. Action Research Projects. 18. Retrieved from http://digitalcommons.unl.edu/ mathmidactionresearch/18

Woodcock, B., Middleton, A., \& Nortcliffe, A. (2012). Considering the Smartphone Learner: developing innovation to investigate the opportunities for students and their interest. Student Engagement and Experience Journal, 1(1), 1-15. https://doi.org/10.7190/seej.v1i1.38 